Journal of Orthopaedic Research

\title{
Antibacterial activity of a new broad-spectrum antibiotic covalently bound to titanium surfaces
}

\begin{tabular}{|c|c|}
\hline Journal: & Journal of Orthopaedic Research \\
\hline Manuscript ID & JOR-15-0774 \\
\hline Wiley - Manuscript type: & Research Article (Non-Member) \\
\hline Date Submitted by the Author: & 07-Dec-2015 \\
\hline Complete List of Authors: & $\begin{array}{l}\text { Gerits, Evelien; KU Leuven, Centre of microbial and plant genetics } \\
\text { Kucharíková, Soňa; VIB, Department of Molecular Microbiology; KU } \\
\text { Leuven, Laboratory of Molecular Cell Biology } \\
\text { Van Dijck, Patrick; VIB, Department of Molecular Microbiology; KU Leuven, } \\
\text { Laboratory of Molecular Cell Biology } \\
\text { Erdtmann, Martin; Hemoteq AG } \\
\text { Krona, Annika; SP Food and Bioscience, Department of structure and } \\
\text { material design } \\
\text { Lövenklev, Maria; SP Food and Bioscience, Department of structure and } \\
\text { material design } \\
\text { Fröhlich, Mirjam; Educell Ltd; University of Ljubljana, Faculty of Medicine, } \\
\text { Institute of Cell Biology } \\
\text { Dovgan, Barbara; Educell Ltd } \\
\text { Impellizzeri, Frédéric; Biotech International } \\
\text { Braem, Annabel; KU Leuven, Department of Materials Engineering (MTM) } \\
\text { Vleugels, Jef; KU Leuven, Department of Materials Engineering (MTM) } \\
\text { Robijns, Stijn; KU Leuven, Centre of Microbial and Plant Genetics } \\
\text { Steenackers, Hans; KU Leuven, Centre of Microbial and Plant Genetics } \\
\text { Vanderleyden, Jozef; KU Leuven, Centre of Microbial and Plant Genetics } \\
\text { De Brucker, Katrijn; KU Leuven, Centre of Microbial and Plant Genetics } \\
\text { Thevissen, Karin; KU Leuven, Centre of Microbial and Plant Genetics } \\
\text { Cammue, Bruno; KU Leuven, Centre of Microbial and Plant Genetics; VIB, } \\
\text { Department of Plant Systems Biology } \\
\text { Fauvart, Maarten; KU Leuven, Centre of Microbial and Plant Genetics; } \\
\text { imec, Smart Systems and Emerging Technologies Unit } \\
\text { Verstraeten, Natalie; KU Leuven, Centre of Microbial and Plant Genetics } \\
\text { Michiels, Jan; KU Leuven, Centre of Microbial and Plant Genetics }\end{array}$ \\
\hline Areas of Expertise: & $\begin{array}{l}\text { Staphylococcus aureus, Pseudomonas aeruginosa, SPI031, biofilm, } \\
\text { titanium }\end{array}$ \\
\hline Keywords: & \\
\hline
\end{tabular}


SCHOLARONE $^{m}$
Manuscripts

John Wiley \& Sons, Inc. 


\section{TITLE}

2 Antibacterial activity of a new broad-spectrum antibiotic covalently bound to titanium

3 surfaces

4

5 RUNNING TITLE

$6 \quad$ Antibacterial SPI031-coated titanium surfaces

7

\section{AUTHORS}

9 Evelien Gerits ${ }^{1}$, Soňa Kucharíková ${ }^{2,3}$, Patrick Van Dijck ${ }^{2,3}$, Martin Erdtmann ${ }^{4}$, Annika 10 Krona $^{5}$, Maria Lövenklev ${ }^{5}$, Mirjam Fröhlich ${ }^{6,7}$, Barbara Dovgan ${ }^{6}$, Frédéric Impellizzeri ${ }^{8}$, 11 Annabel Braem ${ }^{9}$, Jef Vleugels ${ }^{9}$, Stijn C.A. Robijns ${ }^{1}$, Hans P. Steenackers ${ }^{1}$, Jozef 12 Vanderleyden ${ }^{1}$, Katrijn De Brucker ${ }^{1}$, Karin Thevissen ${ }^{1}$, Bruno P.A. Cammue ${ }^{1,10}$, Maarten 13 Fauvart ${ }^{1,11}$, Natalie Verstraeten ${ }^{1}$ and Jan Michiels ${ }^{1} *$

14

$15{ }^{1}$ Centre of Microbial and Plant Genetics, KU Leuven, Kasteelpark Arenberg 20 box 2460, 163001 Leuven, Belgium

$17{ }^{2}$ Department of Molecular Microbiology, VIB, KU Leuven, Kasteelpark Arenberg 31 box $18 \quad 2438,3001$ Leuven, Belgium

$19{ }^{3}$ Laboratory of Molecular Cell Biology, KU Leuven, Kasteelpark Arenberg 31 box 2438, 203001 Leuven, Belgium

$21 \quad{ }^{4}$ Hemoteq AG, Adenauerstraße 15, 52146 Wuerselen, Germany 
$22{ }^{5}$ Department of structure and material design, SP Food and Bioscience, Box 5401, 40229

23 Gothenburg, Sweden

$24 \quad{ }^{6}$ Educell Ltd, Prevale 9, 1236 Trzin, Slovenia

$25{ }^{7}$ Faculty of Medicine, Institute of Cell Biology, University of Ljubljana, Vrazov trg 2, 1000

26 Ljubljana, Slovenia

$27{ }^{8}$ Biotech International, Allées de Craponne 305 - 13300 Salon-de-Provence, France

$28{ }^{9}$ Department of Materials Engineering (MTM), KU Leuven, Kasteelpark Arenberg 44 box

29 2450, 3001 Leuven, Belgium

$30{ }^{10}$ Department of Plant Systems Biology, VIB, Technologiepark 927, 9052 Ghent, Belgium

$31{ }^{11}$ imec, Smart Systems and Emerging Technologies Unit, Department of Life Science

32 Technologies, Kapeldreef 75, 3001 Leuven, Belgium

33

34 *Correspondence to: Jan Michiels (Telephone: +32 16 321631; Fax: +32 16 321966; E-mail:

35 Jan.Michiels@biw.kuleuven.be)

36

37 AUTHOR CONTRIBUTION

38 In vitro experiments were designed by E.G., M.Fa., N.V. and J.M. and performed by E.G.

39 Microscopic analysis was performed by A.K and M.L. In vivo experiments were carried out

40 by S.K. and P.V.D. Cytotoxicity was assessed by M.Fr. and B.D. Ti discs were produced by

41 F.I. and covalently coated by M.E. The surface roughness profile was determined by A.B. and

42 J.Vl., S.C.A.R., H.P.S, J.Va., K.D.B., K.T. and B.P.A.C. coordinated the study. The

43 manuscript was written by E.G. and edited by N.V. and J.M. All authors have read and

44 approved the final manuscript. 
2

\section{ABSTRACT}

Biofilm-associated infections, particularly those caused by Staphylococcus aureus, are a major cause of implant failure. Covalent coupling of broad-spectrum antimicrobials to implants is a promising approach to reduce the risk of infections. In this study, we developed titanium substrates on which the recently discovered antibacterial agent SPI031, a N-alkylated 3, 6-dihalogenocarbazol 1-(sec-butylamino)-3-(3,6-dichloro-9H-carbazol-9-yl)propan-2-ol, was covalently linked (SPI031-Ti). We found that SPI031-Ti substrates prevent biofilm formation of S. aureus and Pseudomonas aeruginosa in vitro, as quantified by plate counting and fluorescence microscopy. To test the effectiveness of SPI031-Ti substrates in vivo, we used an adapted in vivo biomaterial-associated infection model in mice in which SPI031-Ti substrates were implanted subcutaneously and subsequently inoculated with $S$. aureus. Using this model, we found a significant reduction in biofilm formation (up to $98 \%$ ) on SPI031-Ti substrates compared to control substrates. Finally, we demonstrated that the functionalization of the titanium surfaces with SPI031 did not influence the adhesion and proliferation of human cells important for osseointegration and bone repair. In conclusion, these data demonstrate the clinical potential of SPI031 to be used as an antibacterial coating for implants, thereby reducing the incidence of implant-associated infections.

\section{KEY WORDS}

\section{Staphylococcus aureus, Pseudomonas aeruginosa, SPI031, biofilm, titanium}


68

69

71

72

73

74

75

76

77

78

79

80

81

82

83

84

85

86

87

88

89

\section{INTRODUCTION}

The use of implant devices has risen exponentially in the last decades. However, the introduction of foreign material into the human body significantly increases the risk of infection. ${ }^{1}$ As such, implant-associated infections have become a major cause of implant failure. $^{2,3}$ These infections are difficult to treat and in most cases, removal of the implant followed by a long-term antimicrobial treatment is the only remedy. ${ }^{4}$ This leads to increased morbidity and mortality and puts a great financial burden on healthcare systems. ${ }^{3}$ Implant-related infections are frequently caused by Gram-positive staphylococci such as Staphylococcus aureus and by Gram-negative rod-shaped bacteria such as Pseudomonas aeruginosa. ${ }^{5}$ It is widely accepted that biofilm formation plays a key role in the development of these infections. ${ }^{6,7}$ These biofilms consist of a microbial community embedded in a matrix of extracellular polymeric substances. Generally, biofilms are 10 to 1000 times more resistant to antimicrobials, severely hampering the successful treatment of biofilm-associated infections. $^{8}$

Various approaches have been reported to reduce the infection rates associated with implant devices, including the development of antimicrobial coatings on implant surfaces. ${ }^{9,10}$ These coatings can be classified as active or passive. Active coatings are designed to release high amounts of antimicrobial agents, such as antibiotics and antiseptics, immediately after implantation. ${ }^{11}$ However, this strategy has some limitations such as an elevated local toxicity and a reduced long-term activity. ${ }^{9}$ Therefore, recent research has focused on the development of passive coatings that do not release antimicrobial agents but inhibit microbial adherence to the implant and/or kill the pathogen by contact. ${ }^{12-19}$ 
90 Recently, we identified a N-alkylated 3, 6-dihalogenocarbazol 1-(sec-butylamino)-3-(3,691 dichloro-9H-carbazol-9-yl)propan-2-ol as an antibacterial compound. This compound, 92 SPI031, exhibits broad-spectrum antibacterial activity against Gram-positive and Gram93 negative pathogens, including $S$. aureus and $P$. aeruginosa. ${ }^{20}$ In the present study, we 94 investigated the potential of SPI031 for use as a passive implant coating. We show that 95 titanium (Ti) surfaces can be successfully functionalized with SPI031. In addition, we 96 demonstrate that SPI031-functionalized Ti substrates significantly prevent colonization by $S$. 97 aureus and $P$. aeruginosa in vitro. Moreover, we corroborated these observations in vivo, 98 using a $S$. aureus biomaterial-associated murine infection model. Finally, we show that the 99 functionalized Ti substrates support osseointegration potential in vitro.

MATERIAL AND METHODS

\section{Bacterial strains and chemicals}

103 S. aureus SH1000 cells ${ }^{21}$ and $P$. aeruginosa cells PA14 ${ }^{22}$ were grown at $37^{\circ} \mathrm{C}$ in Trypticase

104 Soy Broth (TSB, Becton Dickinson Benelux) or on solid TSB medium containing 1.5 \% agar. 105 SPI031 was supplied by the Centre for Drug Design and Discovery (CD3, Leuven, Belgium). 106

\section{Covalent binding of SPI031 to Ti discs}

108 To enhance osseointegration, one side of round titanium discs (commercially pure titanium,

109 grade 2; height: $2 \mathrm{~mm}$; diameter: $5 \mathrm{~mm}$ ) were first roughened by bead blasting with high

110 purity $\mathrm{Al}_{2} \mathrm{O}_{3}$ particles, followed by etching using an acid mixture and finally by washing with

111 isopropanol. A 3D surface roughness analysis was performed by white light interferometry

112 (Wyko NT 3300 Optical Profiler, Veeco Instruments, Mannheim, Germany), measuring a 
113 total of ten positions distributed over two samples. The roughness data were analyzed using 114 the MountainsMapH Premium software (Digital Surf, Besançon, France), showing an average 115 surface roughness, $S_{a}$, of $0.69 \pm 0.10 \mu \mathrm{m}$, while the ten point height (average height of the 5 116 highest and 5 lowest points), $\mathrm{S}_{\mathrm{z}}$, and the developed interfacial area ratio, $\mathrm{S}_{\mathrm{dr}}$, amounted $8.90 \pm$ $1172.00 \mu \mathrm{m}$ and $2.69 \pm 1.11 \%$, respectively. Next, discs were functionalized by coupling with 118 Fmoc-protected 3-aminopropyl-triethoxy silane ${ }^{23}$ and were deprotected by piperidine in 119 tetrahydrofuran (90:10). Discs were first placed in a hydrolysis vessel containing $45 \mathrm{~mL} \mathrm{n-}$ 120 heptane / hexamethylene diisocyanate $(85: 15)$ for $3 \mathrm{~h}$ at room temperature. Subsequently, 121 discs were rinsed with n-heptane and were covalently linked to SPI031 by placing them in a 122 solution containing $30 \mathrm{~mL}$ DMSO and $0.050 \mathrm{~g}$ SPI031 for $16 \mathrm{~h}$ with gentle agitation. Finally, 123 the covalently linked SPI031-Ti discs were washed three times with DMSO, three times with 124 demineralised, pyrogen-free water and finally with acetone, and were subsequently allowed to 125 dry.

Quantification of SPI031 attached to Ti discs by high-performance liquid chromatography (HPLC)

129 The amount of immobilized SPI031 on the Ti discs was measured via HPLC upon hydrolysis, 130 resulting in release of bound compound. To this end, SPI031-Ti discs were placed in 131 hydrolysis vessels containing $1 \mathrm{~mL}$ demineralized water, $0.5 \mathrm{~mL}$ isopropanol and $1 \mathrm{~mL}$ 132 triethylamine. The vessels were locked and heated to $60^{\circ} \mathrm{C}$ for $1 \mathrm{~h}$. Subsequently, the solvents 133 were evaporated at $60{ }^{\circ} \mathrm{C}$ and the residues were dissolved in $0.5 \mathrm{~mL}$ demineralized water. The 134 amount of SPI031 in the residues was quantified using HPLC equipped with a C18 column 
$135(50 \times 2.1 \mathrm{~mm})$. The SPI031-Ti discs remained stable for at least 12 months when stored at 4 $136{ }^{\circ} \mathrm{C}$.

137

138

139

140

141

142

143

144

145

146

147

148

149

150

151

152 153 calculated.

\section{In vitro quantification of biofilm formation on SPI031-Ti discs}

Before biofilm formation, control-Ti and SPI031-Ti discs were incubated in Fetal Bovine Serum (FBS, Life Technologies, Europe) overnight at $37^{\circ} \mathrm{C}$, to mimic the in vivo

environment of the human tissue. Next, the discs were washed in PBS and transferred to the wells of a 24 -well plate. Sterile silicon tubes $(9 \mathrm{~mm}$ OD x $5 \mathrm{~mm} \mathrm{ID} \times 15 \mathrm{~mm} \mathrm{~L})(\mathrm{VWR}$ International) were placed over the discs to exclude the, non-rough, sides and bottoms.

Subsequently, $0.2 \mathrm{~mL}$ of a $1 \times 10^{4}$ cells $/ \mathrm{mL}$ suspension of $S$. aureus or $P$. aeruginosa in $1 / 20$ TSB was added to the discs and biofilms were allowed to grow for $24 \mathrm{~h}$ at $37^{\circ} \mathrm{C}$ under static conditions. Biofilms formed on the discs were quantified by colony forming unit (CFU) counting. To this end, discs were washed with PBS to remove non-adherent cells, transferred to centrifuge tubes containing $1 \mathrm{~mL}$ PBS, vortexed for $1 \mathrm{~min}$, sonicated at 45,000 $\mathrm{Hz}$ in a water bath sonicator (VWR USC 300-T) for $10 \mathrm{~min}$ and vortexed again. This procedure effectively removed the biofilms attached to the discs. The resulting suspensions containing the detached cells were serially diluted in a $10 \mathrm{mM} \mathrm{MgSO}_{4}$ solution and spread on TSB agar plates. After $24 \mathrm{~h}$ of incubation at $37^{\circ} \mathrm{C}$, colonies were counted and CFUs per mL were

155 Confocal laser scanning microscopy (CLSM) analysis

156 S. aureus and P. aeruginosa biofilms were grown as described above on control-Ti and 157 SPI031-Ti discs, and were stained using the LIVE/DEAD BacLight stain (Molecular Probes, 
158

159

160

161

162

163

164

165

166

167

168 169

170

171

172

173

174

175

176

177

178

179

180

USA) following the manufacturer's instructions. Biofilm images were acquired using a

CLSM (Leica TCS SP5, Heidelberg, Germany) in an inverted microscope configuration.

Biofilms were observed using a HCX PL APO CS 63x/1.2 water-immersion objective. During

CLSM analysis, 25 digital images with 2048 x 2048 resolutions were taken with X-Y scan a

few $\mu \mathrm{m}$ above the surface plane. The laser emissions used to excite the LIVE and DEAD

stains were argon $(488 \mathrm{~nm})$ and $\mathrm{HeNe}(594 \mathrm{~nm})$, respectively. Images obtained by CLSM

were analyzed in Matlab using an in-house developed software macro to quantify the area

fraction of live and dead cells in a thin optical section close to the surface of the disc. This

macro is made to automatically run large series of images by subtracting the background, removing artifacts smaller than 20 pixels and calculating the area covered by objects over a set intensity.

\section{In vivo quantification of biofilm formation on SPI031-Ti discs}

All in vivo experiments were approved by the Animal Ethical Committee of the KU Leuven (project number P125/2011). Female pathogen-free BALB/c mice (20 g, 8 weeks of age) were purchased from Janvier (France). Mice were maintained in individually ventilated cages (4 mice/cage) and were allowed ad libitum access to sterile food and water. $24 \mathrm{~h}$ before surgery, the mice were immunosuppressed by the addition of $0.4 \mathrm{mg} / \mathrm{L}$ dexamethasone to the drinking water. The immunosuppression was maintained throughout the entire experiment. At the day of surgery, mice were anesthetized intraperitoneally with a mixture of ketamine (Ketamine $1000^{\circledR}$; Pfizer, Puurs, Belgium) and medetomidine (Domitor ${ }^{\circledR}$; Pfizer) (45 mg/kg ketamine and $0.6 \mathrm{mg} / \mathrm{kg}$ medetomidine), followed by shaving and disinfecting of the lower back by iodine isopropanol (1\%) and administration of local anesthesia (xylocaine gel $2 \%$, 
181

182

183

184 185 186 187 188 189 190

AstraZeneca, Zoetermeer, the Netherlands). A subcutaneous incision of approximately $2 \mathrm{~cm}$ long and $1 \mathrm{~cm}$ wide was made for the implant of 1 disc. After implant, the wound was closed with surgical staples, disinfected and locally anesthetized with xylocaine gel. An intraperitoneal injection of atipamezole was used to reverse anesthesia (Antisedan; Pfizer, 0.5 $\mathrm{mg} / \mathrm{kg}$ for mice). $24 \mathrm{~h}$ after implant, the mice were anesthetized with a mixture of ketamine and medetomidine as described above. Next, the discs were inoculated with a bacterial culture of $S$. aureus which was washed and resuspended in sterile saline $(0.9 \%)$ to a concentration of $1 \times 10^{8}$ cells $/ \mathrm{mL} .100 \mu \mathrm{l}$ of the bacterial inoculum was injected subcutaneously into the area around the disc. Anesthesia was reversed with an intraperitoneal injection of atipamezole as mentioned above. After 4 days of biofilm formation, mice were euthanized by cervical dislocation. The skin was disinfected $(0.5 \%$ chlorhexidine in $70 \%$ alcohol $)$ and the discs and the surrounding tissue were removed. Biofilm formation on the discs was quantified by $\mathrm{CFU}$ counts. Briefly, discs were washed two times with PBS, sonicated at 40,000 Hz in a water bath sonicator (Branson 2210) for $10 \mathrm{~min}$ and vortexed for $30 \mathrm{~s}$ in $1 \mathrm{~mL}$ PBS. The tissue surrounding the discs was weighed and homogenized. The resulting bacterial suspensions (discs and surrounding tissues) were diluted and plated on TSB agar plates in duplicate. After $24 \mathrm{~h}$ of incubation at $37^{\circ} \mathrm{C}$, CFUs were counted.

\section{Effect of SPI031-coating on the osseointegration response in vitro}

To test the osseointegration potential of SPI031-coated discs, human bone marrow derived stromal cells (MSC) and human microvascular endothelial cells (HMVEC) were used. MSC were cultured in advanced Dulbecco's Modified Eagle Medium (Life Technologies, USA) supplemented with $10 \%$ FBS, 1x GlutaMAX and $0.05 \mathrm{mg} / \mathrm{mL}$ gentamicin (Gibco, Carlsbad, 
204 CA). HMVEC were grown in medium 131 supplemented with Microvascular Growth

205 Supplement (Life Technologies, USA). Cells were seeded at a cell density of $5000 \mathrm{cells} / \mathrm{cm}^{2}$

206 and cultured in $5 \% \mathrm{CO}_{2}$ at $37{ }^{\circ} \mathrm{C}$ for one passage. After reaching $95 \%$ confluence, cells were

207 trypsinized (Trypsin-EDTA, Sigma Aldrich) and counted with a hemocytometer. Cells of the

$2084^{\text {th }}$ passage were used for the experiments.

209 Subsequently, the control-Ti and SPI031-Ti discs were placed into the wells of a 24-well plate

210 and were seeded with cells at a cell density of 9000 cells/disc. The discs were kept in the

211 incubator to allow attachment and after $30 \mathrm{~min}$, additional culture medium was added. Cells

212 were cultured for 5 or 12 days, and were then fixed with formalin for $15 \mathrm{~min}$ and washed 3

213 times with PBS. Then, cells were incubated in a Phalloidin solution (stock solution 0.1

$214 \mathrm{mg} / \mathrm{mL}$ in methanol diluted 1:20 in PBS) to stain actin filaments. After 30 min of incubation

215 in the dark at room temperature, the discs were washed 3 times with PBS and were incubated

216 in a Vectashield/DAPI (Vector Laboratories, USA) solution to stain nuclei. All samples were

217 imaged with a 40x objective on a Nikon T300 fluorescent microscope.

218

219 Statistical analysis

220 All in vitro experiments were carried out in technical duplicates and were independently

221 repeated at least 3 times. The in vivo experiment was performed twice using 11 mice

222 implanted with control-Ti discs and 15 mice implanted with SPI031-Ti discs. Statistical

223 significance of data was determined by applying a student's t-test (Mann-Whitney test) using

224 GraphPad Prism version 5 (GraphPad Software, USA). Differences were considered

225 significant if $* p<0.05$.

226 


\section{RESULTS}

\section{SPI031 prevents biofilm formation by $S$. aureus and $P$. aeruginosa on Ti discs in vitro}

We covalently linked SPI031 to titanium discs as described in Materials and Methods. The amount of SPI031 coated on the discs was $54.8 \mathrm{pmol} / \mathrm{cm}^{2}$ as determined by HPLC. To examine the antibiofilm activity of the SPI031-Ti discs in vitro, control-Ti and SPI031-Ti discs were inoculated with $S$. aureus and P. aeruginosa cells and biofilms were grown for 24 $\mathrm{h}$ where after CFUs were determined. As shown in Figure 1, there was a significant reduction of bacterial colonization of the substrates $(70 \%$ for $S$. aureus and $87 \%$ for $P$. aeruginosa, $\mathrm{p}<$ 0.05). To confirm these results, biofilm growth on the control-Ti and SPI031-Ti discs was visualized by CLSM using the LIVE/DEAD stain consisting of a mixture of the SYTO 9 (green) and propidium iodide (red) nucleic acid fluorescent stains. SYTO 9 is used to label all cells in a bacterial population while propidium iodide only penetrates cells with damaged membranes. CLSM imaging also revealed a significant reduction of biofilm formation on SPI031-Ti discs, compared to the control-Ti discs (Figure 2A). Next, the area fraction covered by the biofilms on the discs was calculated. As seen in Figure 2B, the viable area fraction of staphylococcal and pseudomonal biofilms was significantly reduced on SPI031-Ti discs.

\section{SPI031 prevents biofilm formation by $S$. aureus in a murine infection model}

The activity of the SPI031-Ti discs under in vivo conditions was assessed using an adapted model of biomaterial-associated infection, which was originally developed to study $S$. epidermidis biofilm development on titanium and silicone substrates. ${ }^{24}$ Briefly, the control-Ti and SPI031-Ti discs were implanted subcutaneously and the tissue adjacent to the discs was challenged with $\sim 10^{7} \mathrm{~S}$. aureus cells to allow in vivo biofilm formation. After 4 days of 
250 biofilm development, control-Ti discs contained on average $5.39 \log _{10}$ CFUs. In comparison,

251 SPI031-Ti discs contained on average $4 \log _{10}$ CFUs, which corresponds to a significant

252 reduction of $98 \%(\mathrm{p}<0.05)($ Figure $3 \mathrm{~A})$. Individual data points of each mouse are shown in

253 Supplementary Figure S1. In addition, analysis of the tissue surrounding the implanted discs

254 revealed a similar amount of bacteria colonizing the tissue surrounding the control-Ti and

255 SPI031-Ti discs (Figure 3B), indicating that SPI031 was not or only minimally released from

256 the discs.

257

258 SPI031-Ti does not affect osseointegration potential

259 Osseointegration, the close interaction of living bone tissue with implants, is an important

260 factor in implant success. ${ }^{25}$ Therefore, we assessed if the coated discs affected adhesion and

261 proliferation of osteogenic (MSC) and vasculogenic (HMVEC) cells, two cell types that are

262 known to be involved in osseointegration and bone repair. ${ }^{25}$ In this assay, cells were

263 visualized by staining their actin filaments (Phalloidin) and DNA (DAPI) after 5 or 12 days of

264 incubation on control-Ti and SPI031-Ti discs, and cell attachment and growth were evaluated

265 visually. The surfaces of the control-Ti and SPI031-Ti discs supported attachment and growth

266 of MSC and HMVEC cells equally, suggesting that a suitable level of osseointegration can

267 occur upon implantation of SPI031-coated implants (Figure 4).

268

269 DISCUSSION

270 Biomaterial-related infections are a major problem in implant surgery and impose a huge

271 economic burden on healthcare systems. ${ }^{2,3}$ Covalent immobilization of antibacterial agents on

272 implant surfaces has been explored to inhibit these infections. ${ }^{12-19}$ Although these coatings 
273 have proven their effectiveness in vitro, it remains important to develop coatings with new

274 antibacterial agents, thereby lowering the risk of developing antibiotic resistance.

275 In this study, we evaluated the antibiofilm properties and biocompatibility of titanium

276 surfaces covalently coated with the new antibacterial compound SPI031, a N-alkylated 3,6-

277 dihalogenocarbazol 1-(sec-butylamino)-3-(3,6-dichloro-9H-carbazol-9-yl)propan-2-ol.

278 Silanization was used to covalently link the new antibacterial compound to titanium surfaces.

279 This technique has previously been demonstrated to be an effective method for covalent

280 coating of bioactive molecules to metallic surfaces ${ }^{26}$ and the procedure employed in this study

281 is carried out at ambient conditions, implying that this coating strategy is suitable for large-

282 scale production of coated implants. ${ }^{19}$ Furthermore, to our knowledge, this is the first study

283 describing the development of an implant coating using a new non-peptide antibiotic, thereby

284 possibly overcoming some disadvantages associated with peptide-based coatings such as

285 reduced in vivo activity and potential toxicity. ${ }^{27}$

286 We demonstrated previously that SPI031 exhibits broad-spectrum antibacterial activity.

287 Moreover, this compound does not exert a cytotoxic effect on several human cell types at the

288 tested concentrations. ${ }^{20}$ In the present study we examined the antibacterial activity of

289 covalently bound SPI031 in vitro by challenging SPI031-Ti substrates with $S$. aureus and $P$.

290 aeruginosa, two bacterial strains frequently involved in implant-related infections. ${ }^{5}$

291 Significantly less bacterial cells were found on the SPI031-Ti discs, compared to the control-

292 Ti discs. Of note, the coated discs were more active against the Gram-positive bacteria $S$.

293 aureus than against the Gram-negative bacteria $P$. aeruginosa. This is likely caused by the

294 fact that, in contrast to Gram-positive bacteria, Gram-negative bacteria possess an outer 
295 membrane, making them less susceptible to antibacterial agents. ${ }^{28}$ These differences in cell

296 wall structure can possibly explain the observed differences in sensitivity.

297 To investigate the antibacterial activity of the SPI031-Ti substrates in vivo, a mouse

298 biomaterial-associated model of infection was used. Strikingly, under these conditions $S$.

299 aureus biofilm development on SPI031-Ti substrates was reduced by $98 \%$, compared to

300 control substrates. It is likely that this reduction in staphylococcal colonization is sufficient to

301 allow further clearance of the infection by the host defense mechanism. ${ }^{29}$ It is noteworthy to

302 mention that in this study S. aureus biofilm development was followed for 4 days. However,

303 no difference was found between the number of bacteria in the tissue surrounding the control-

304 Ti and SPI031-Ti discs, indicating that SPI031 was not released from the implant. Covalent

305 coatings are known for their long-lasting effects ${ }^{30}$, suggesting that potential biofilm formation

306 on the coated discs can be inhibited for longer periods of time.

307 We previously demonstrated the in vitro and in vivo efficacy of covalently bound

308 vancomycin, a glycopeptide antibiotic active against Gram-positive bacteria. ${ }^{19}$ Our SPI031-

309 coated substrates appear to be as active as these vancomycin-coated substrates. Moreover,

310 since the SPI031-coated substrates are effective against both Gram-positive and Gram-

311 negative bacteria, we believe this coating has even a wider range of application potential.

312 Next to an anti-bacterial strategy, osseointegration is a prerequisite for successful implant

313 therapy. ${ }^{25}$ Therefore, the osseointegration potential of the discs was evaluated in vitro. No

314 differences in the adhesion and proliferation of mammalian cells important for

315 osseointegration and bone repair were found between the control-Ti and SPI031-Ti discs.

316 These results further support the potential of our coating technique to decrease the incidence

317 of implant-related infections, without compromising osseointegration. 
318 In summary, we were able to covalently link the new antibacterial compound SPI031 to

319 titanium surfaces. Furthermore, these functionalized surfaces showed significant antibacterial

320 activity both in vitro and in vivo without affecting the in vitro osseointegration potential. As

321 such, these results demonstrate the clinical potential of our antibacterial coating. Future

322 studies will be directed at further investigating the toxicity, biocompatibility and

323 osseointegration of this coating in vivo and at evaluating its effectiveness using a clinically

324 relevant orthopedic infection model.

325

326 ACKNOWLEDGMENTS

327 This work was supported by the European Commission's Seventh Framework Programme

328 (FP7/2007-2013) under the grant agreement COATIM (project $\mathrm{n}^{\circ} 278425$ ), by grants from the

329 FWO (G0B2515N, G047112N, WO.026.11N), and the Interuniversity Attraction Poles

330 Programme initiated by the Belgian Science Policy Office. K.T. acknowledges the receipt of a

331 mandate of the 'Industrial Research Fund' of KU Leuven (IOFm/05/022). S.K. acknowledges

332 the receipt of postdoctoral grants of the 'Bijzonder Onderzoeks Fonds' of KU Leuven (grant

333 PDMK 11/089) and the FWO. H.S. acknowledges the receipt of a postdoctoral fellowship

334 from FWO-Vlaanderen. We would like to thank Mrs. Cindy Colombo and Ms. Celia Lobo

335 Romero for their assistance during in vivo experimental procedures. The authors declare no

336 conflict of interest.

337

338 REFERENCES

339 1. Wu H, Moser C, Wang HZ, et al. 2015. Strategies for combating bacterial biofilm

340 infections. Int J Oral Sci 7:1-7. 
341 2. Von Eiff C, Jansen B, Kohnen W, Becker K. 2005. Infections associated with medical 342 devices: pathogenesis, management and prophylaxis. Drugs 65:179-214.

343 3. Darouiche RO. 2004. Treatment of infections associated with surgical implants. N Engl $344 \quad$ J Med 350:1422-1429.

345 4. Toms AD, Davidson D, Masri BA, Duncan CP. 2006. The management of peri346 prosthetic infection in total joint arthroplasty. J Bone Joint Surg Br 88:149-155.

347 5. Campoccia D, Montanaro L, Arciola CR. 2006. The significance of infection related to 348 orthopedic devices and issues of antibiotic resistance. Biomaterials 27:2331-2339.

6. Costerton JW. 2005. Biofilm theory can guide the treatment of device-related 350 orthopaedic infections. Clin Orthop Relat Res 437:7-11.

351 7. Dunne WM. 2002. Bacterial adhesion: seen any good biofilms lately? Clin Microbiol $352 \quad$ Rev 15:155-166.

353 8. Mah TF, O’Toole GA. 2001. Mechanisms of biofilm resistance to antimicrobial agents 354 Trends Microbiol 9:34-39.

355 9. Zhao L, Chu PK, Zhang Y, Wu Z. 2009. Antibacterial coatings on titanium implants. J 356 Biomed Mater Res B Appl Biomater 91:470-480.

357 10. Hasan J, Crawford RJ, Ivanova EP. 2013. Antibacterial surfaces: the quest for a new 358 generation of biomaterials. Trends Biotechnol 31:295-304. 
359 11. Hetrick EM, Schoenfisch MH. 2006. Reducing implant-related infections: active $360 \quad$ release strategies. Chem Soc Rev 35:780-789.

361 12. Costa F, Carvalho IF, Montelaro RC, et al. 2011. Covalent immobilization of 362 antimicrobial peptides (AMPs) onto biomaterial surfaces. Acta Biomater 7:1431-1440.

363 13. Holmberg KV, Abdolhosseini M, Li Y, et al. 2013. Bio-inspired stable antimicrobial 364 peptide coatings for dental applications. Acta Biomater 9:8224-8231.

365 14. Godoy-Gallardo M, Mas-Moruno C, Fernández-Calderón MC, et al. 2014. Covalent 366 immobilization of hLf1-11 peptide on a titanium surface reduces bacterial adhesion and biofilm formation. Acta Biomater 10:3522-3534.

368 15. Antoci VJr, King SB, Jose B, et al. 2007. Vancomycin covalently bonded to titanium 369 alloy prevents bacterial colonization. J Orthop Res 25:858-866.

370 16. Davidson H, Poon M, Saunders R, et al. 2014. Tetracycline tethered to titanium inhibits 371 colonization by Gram-negative bacteria. J Biomed Mater Res B Appl Biomater 1-9.

372 17. Chen CP, Wickstrom E. 2010. Self-protecting bactericidal titanium alloy surface 373 formed by covalent bonding of daptomycin bisphosphonates. Bioconjug Chem $374 \quad 21: 1978-1986$.

375 18. Aumsuwan N, Heinhorst S, Urban MW. 2007. Antibacterial surfaces on expanded 376 polytetrafluoroethylene; penicillin attachment. Biomacromolecules 8:713-718. 
377 19. Kucharíková S, Gerits E, De Brucker K, et al. 2015. Covalent immobilization of

378 antimicrobial agents on titanium prevents Staphylococcus aureus and Candida albicans

379 colonization and biofilm formation. J Antimicrob Chemother. In press. DOI:

$380 \quad 10.1093 / \mathrm{jac} / \mathrm{dkv} 437$.

381 20. Liebens V, Gerits E, Knapen WJ, et al. 2014. Identification and characterization of an 382 anti-pseudomonal dichlorocarbazol derivative displaying anti-biofilm activity. Bioorg 383 Med Chem Lett 24:5404-5408.

21. O’Neill AJ. 2010. Staphylococcus aureus SH1000 and 8325-4: comparative genome 385 sequences of key laboratory strains in staphylococcal research. Lett Appl Microbiol 51:358-361.

22. Lee DG, Urbach JM, Wu G, et al. 2006. Genomic analysis reveals that Pseudomonas aeruginosa virulence is combinatorial. Genome Biol 7:R90.

23. Carpino LA. 1987. The 9-fluorenylmethoxycarbonyl family of base-sensitive aminoprotecting groups. Acc Chem Res 20:401-407.

24. Riool M, de Boer L, Jaspers V, et al. 2014. Staphylococcus epidermidis originating from titanium implants infects surrounding tissue and immune cells. Acta Biomater 10:5202-5212.

25. Agarwal R, García AJ. 2015. Biomaterial strategies for engineering implants for enhanced osseointegration and bone repair. Adv Drug Deliv Rev 94:53-62. 
396 26. Hickock NJ, Shapiro IM. 2013. Immobilized antibiotics to prevent orthopedic implant 397 infections. Adv Drug Deliv Rev 64:1165-1176.

398 27. Marr AK, Gooderham WJ, Hancock RE. 2006. Antibacterial peptides for therapeutic 399 use: obstacles and realistic outlook. Curr Opin Pharmacol 6:468-472.

400 28. Delcour AH. 2010. Outer membrane permeability and antibiotic resistance. Biochim 401 Biophys Acta 1794:808-816.

402 403

404

405

406

407

408

409

410

411

412

413

414

415

416

29. Stewart S, Barr S, Engiles J, et al. 2012. Vancomycin-modified implant surface inhibits biofilm formation and supports bone-healing in an infected osteotomy model in sheep: a proof-of-concept study. J Bone Joint Surg Am 94:1406-1415.

30. Ketonis C, Parvizi J, Jones LC. 2012. Evolving strategies to prevent implant-associated infections. J Am Acad Orthop Surg 20:478-480.

\section{FIGURE LEGENDS}

Figure 1: In vitro characterization of biofilm formation of $S$. aureus (A) and $P$. aeruginosa (B) on SPI031-Ti discs. Control-Ti and SPI031-Ti discs were inoculated with $S$. aureus and $P$. aeruginosa cells and incubated for $24 \mathrm{~h}$. The results are expressed as percentage of biofilm formation on SPI031-Ti discs relative to control-Ti discs. Data represent the mean \pm standard errors of the means $(\mathrm{SEM})$ of 3 independent experiments $(* \mathrm{p}<$ $0.05)$.

Figure 2: CLSM analysis of biofilm formation of $S$. aureus and $P$. aeruginosa on SPI031Ti discs. Control-Ti and SPI031-Ti discs were inoculated with $S$. aureus and P. aeruginosa 
417 cells and incubated for $24 \mathrm{~h}$. (A) CLSM images of S. aureus and P. aeruginosa biofilms 418 grown on control-Ti and SPI031-Ti discs. Biofilms were stained with SYTO 9 (green; viable 419 cells) and propidium iodide (red; dead cells). (B) The area fraction of live and dead biofilm 420 cells visualized in Figure 2A. Data represent the mean \pm SEM of 3 independent experiments $421(* \mathrm{p}<0.05)$.

422 Figure 3: In vivo characterization of biofilm formation of $S$. aureus on SPI031-Ti discs.

423 Sampling was performed after 4 days of biofilm development. (A) Growth of S. aureus 424 biofilms on control-Ti and SPI031-Ti discs. (B) S. aureus cells found in tissue surrounding 425 control-Ti and SPI031-Ti discs. Data represent the mean \pm SEM of 2 independent 426 experiments $(* \mathrm{p}<0.05)$.

427 Figure 4: In vitro analysis of the osseointegrative potential of SPI031-Ti discs. (A)

428 Visualization of human microvascular endothelial cells bone marrow derived stromal cells 429 grown on control-Ti and SPI031-Ti discs. (B) Visualization of human bone marrow derived 430 stromal cells microvascular endothelial cells grown on control-Ti and SPI031-Ti discs.

$431 \quad$ Figure S1: In vivo characterization of biofilm formation of $S$. aureus on control-Ti and 432 SPI031-Ti discs. Sampling was performed after 4 days of biofilm development. Single data 433 points per mouse and mean \pm SEM per group are shown. 
A

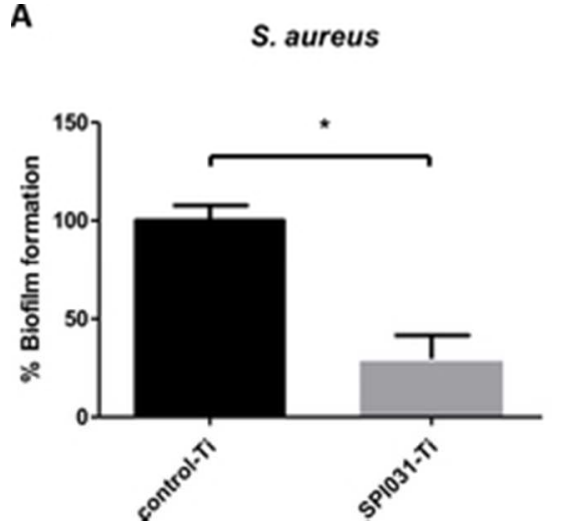

B

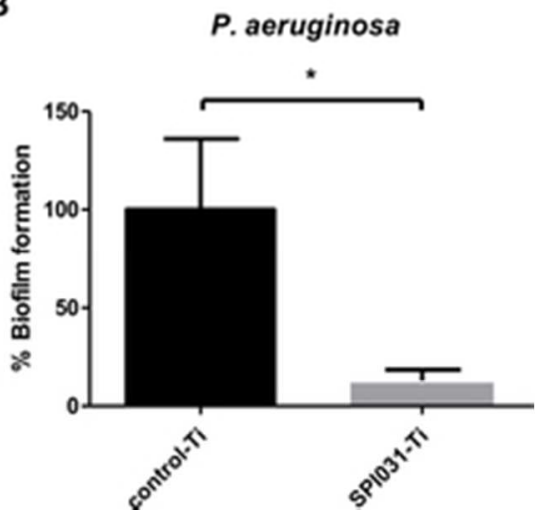

Figure 1: In vitro characterization of biofilm formation of S. aureus (A) and P. aeruginosa (B) on SPI031-Ti discs. Control-Ti and SPI031-Ti discs were inoculated with S. aureus and P. aeruginosa cells and incubated for $24 \mathrm{~h}$. The results are expressed as percentage of biofilm formation on SPI031-Ti discs relative to controlTi discs. Data represent the mean \pm standard errors of the means (SEM) of 3 independent experiments $\left({ }^{*} \mathrm{p}\right.$ $<0.05)$.

$37 \times 16 \mathrm{~mm}(300 \times 300$ DPI $)$ 
A

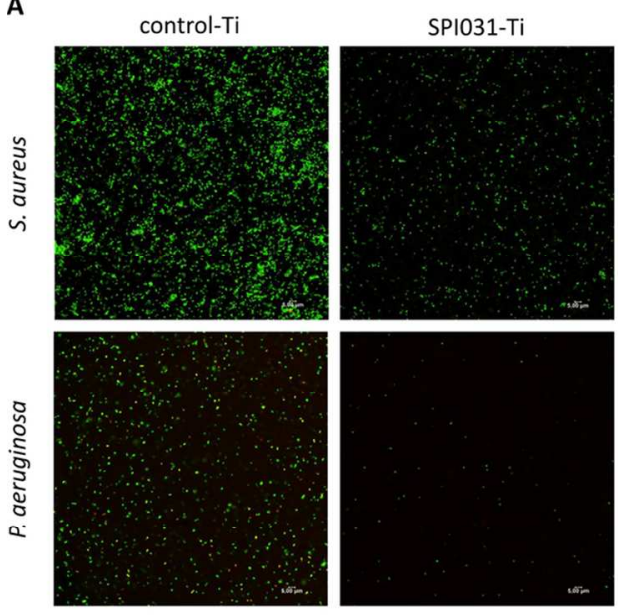

B

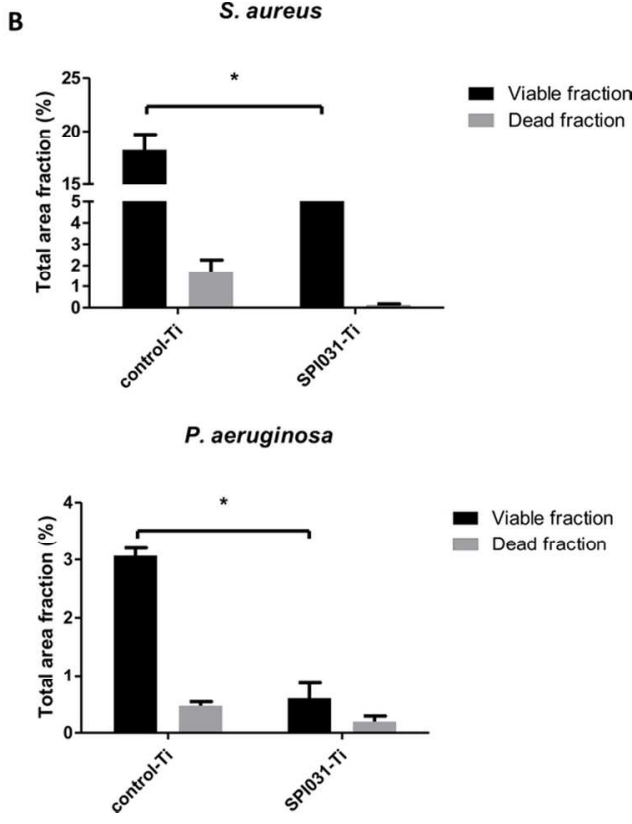

Figure 2: CLSM analysis of biofilm formation of S. aureus and P. aeruginosa on SPI031-Ti discs. Control-Ti and SPI031-Ti discs were inoculated with S. aureus and P. aeruginosa cells and incubated for $24 \mathrm{~h}$. (A) CLSM images of S. aureus and P. aeruginosa biofilms grown on control-Ti and SPI031-Ti discs. Biofilms were stained with SYTO 9 (green; viable cells) and propidium iodide (red; dead cells). (B) The area fraction of live and dead biofilm cells visualized in Figure 2A. Data represent the mean \pm SEM of 3 independent

experiments $(* \mathrm{p}<0.05)$.

$105 \times 65 \mathrm{~mm}(300 \times 300$ DPI $)$ 
A

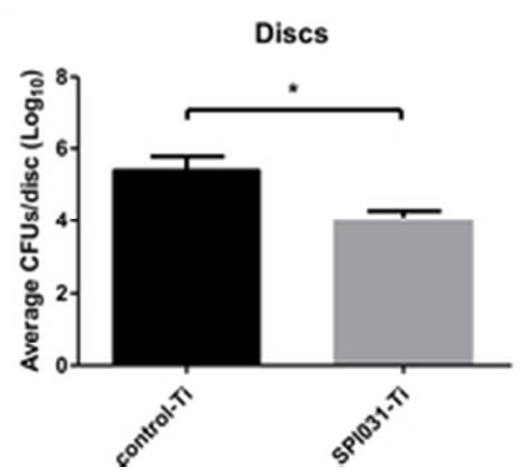

B

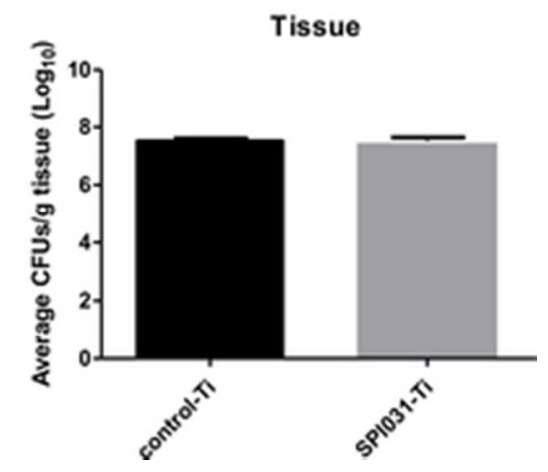

Figure 3: In vivo characterization of biofilm formation of S. aureus on SPI031-Ti discs.

Sampling was performed after 4 days of biofilm development. (A) Growth of S. aureus biofilms on control-Ti and SPI031-Ti discs. (B) S. aureus cells found in tissue surrounding control-Ti and SPI031-Ti discs. Data represent the mean \pm SEM of 2 independent experiments $(* p<0.05)$.

$36 \times 16 \mathrm{~mm}(300 \times 300 \mathrm{DPI})$ 

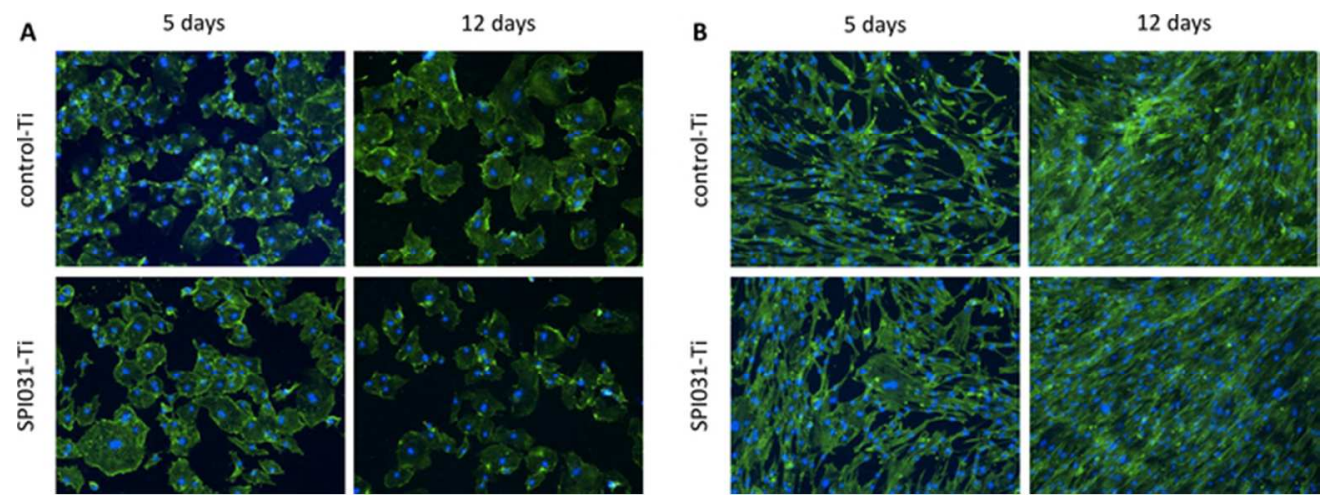

Figure 4: In vitro analysis of the osseointegrative potential of SPI031-Ti discs. (A) Visualization of human microvascular endothelial cells bone marrow derived stromal cells grown on control-Ti and SPI031-Ti discs.

(B) Visualization of human bone marrow derived stromal cells microvascular endothelial cells grown on control-Ti and SPI031-Ti discs. $62 \times 23 \mathrm{~mm}(300 \times 300 \mathrm{DPI})$ 


\section{The ARRIVE Guidelines Checklist}

\section{Animal Research: Reporting In Vivo Experiments}

Carol Kilkenny ${ }^{1}$, William J Browne ${ }^{2}$, Innes C Cuthill ${ }^{3}$, Michael Emerson ${ }^{4}$ and Douglas G Altman ${ }^{5}$

${ }^{1}$ The National Centre for the Replacement, Refinement and Reduction of Animals in Research, London, UK, ${ }^{2}$ School of Veterinary Science, University of Bristol, Bristol, UK, ${ }^{3}$ School of Biological Sciences, University of Bristol, Bristol, UK, ${ }^{4}$ National Heart and Lung Institute, Imperial College London, UK, ${ }^{5}$ Centre for Statistics in Medicine, University of Oxford, Oxford, UK.

\begin{tabular}{|c|c|c|c|}
\hline & ITEM & RECOMMENDATION & $\begin{array}{l}\text { Section/ } \\
\text { Paragraph }\end{array}$ \\
\hline Title & 1 & $\begin{array}{l}\text { Provide as accurate and concise a description of the content of the article } \\
\text { as possible. }\end{array}$ & Title page \\
\hline Abstract & 2 & $\begin{array}{l}\text { Provide an accurate summary of the background, research objectives, } \\
\text { including details of the species or strain of animal used, key methods, } \\
\text { principal findings and conclusions of the study. }\end{array}$ & $\begin{array}{l}\text { Abstract } \\
\text { and } \\
\text { Keywords }\end{array}$ \\
\hline \multicolumn{4}{|l|}{ INTRODUCTION } \\
\hline Background & 3 & $\begin{array}{l}\text { a. Include sufficient scientific background (including relevant references to } \\
\text { previous work) to understand the motivation and context for the study, } \\
\text { and explain the experimental approach and rationale. } \\
\text { b. Explain how and why the animal species and model being used can } \\
\text { address the scientific objectives and, where appropriate, the study's } \\
\text { relevance to human biology. }\end{array}$ & $\begin{array}{l}\text { a. } \\
\text { Introductio } \\
\text { n, } \\
\text { Paragraph } \\
\text { s } 1-3 \\
\text { b. } \\
\text { Introductio } \\
\text { n, } \\
\text { Paragraph } \\
4\end{array}$ \\
\hline Objectives & 4 & $\begin{array}{l}\text { Clearly describe the primary and any secondary objectives of the study, or } \\
\text { specific hypotheses being tested. }\end{array}$ & $\begin{array}{l}\text { Introductio } \\
\mathrm{n}, \\
\text { Paragraph } \\
4\end{array}$ \\
\hline \multicolumn{4}{|l|}{ METHODS } \\
\hline Ethical statement & 5 & $\begin{array}{l}\text { Indicate the nature of the ethical review permissions, relevant licences (e.g. } \\
\text { Animal [Scientific Procedures] Act 1986), and national or institutional } \\
\text { guidelines for the care and use of animals, that cover the research. }\end{array}$ & $\begin{array}{l}\text { Material } \\
\text { and } \\
\text { Methods, } \\
\text { Paragraph } \\
6\end{array}$ \\
\hline Study design & 6 & $\begin{array}{l}\text { For each experiment, give brief details of the study design including: } \\
\text { a. The number of experimental and control groups. } \\
\text { b. Any steps taken to minimise the effects of subjective bias when } \\
\text { allocating animals to treatment (e.g. randomisation procedure) and when } \\
\text { assessing results (e.g. if done, describe who was blinded and when). } \\
\text { c. The experimental unit (e.g. a single animal, group or cage of animals). } \\
\text { A time-line diagram or flow chart can be useful to illustrate how complex } \\
\text { study designs were carried out. }\end{array}$ & $\begin{array}{l}\text { a. Material } \\
\text { and } \\
\text { Methods, } \\
\text { Paragraph } \\
8 \\
\text { b. Material } \\
\text { and } \\
\text { Methods, } \\
\text { Paragraph } \\
6 \\
\text { c. Material } \\
\text { and } \\
\text { Methods, } \\
\text { Paragraph } \\
6\end{array}$ \\
\hline
\end{tabular}




\begin{tabular}{|c|c|c|c|}
\hline $\begin{array}{l}\text { Experimental } \\
\text { procedures }\end{array}$ & 7 & $\begin{array}{l}\text { For each experiment and each experimental group, including controls, } \\
\text { provide precise details of all procedures carried out. For example: } \\
\text { a. How (e.g. drug formulation and dose, site and route of administration, } \\
\text { anaesthesia and analgesia used [including monitoring], surgical } \\
\text { procedure, method of euthanasia). Provide details of any specialist } \\
\text { equipment used, including supplier(s). } \\
\text { b. When (e.g. time of day). } \\
\text { c. Where (e.g. home cage, laboratory, water maze). } \\
\text { d. Why (e.g. rationale for choice of specific anaesthetic, route of } \\
\text { administration, drug dose used). }\end{array}$ & $\begin{array}{l}\text { a. Material } \\
\text { and } \\
\text { Methods, } \\
\text { Paragraph } \\
6 \\
\text { b. Material } \\
\text { and } \\
\text { Methods, } \\
\text { Paragraph } \\
6 \\
\text { c. Material } \\
\text { and } \\
\text { Methods, } \\
\text { Paragraph } \\
6 \\
\text { d. Material } \\
\text { and } \\
\text { Methods, } \\
\text { Paragraph } \\
6\end{array}$ \\
\hline $\begin{array}{l}\text { Experimental } \\
\text { animals }\end{array}$ & 8 & $\begin{array}{l}\text { a. Provide details of the animals used, including species, strain, sex, } \\
\text { developmental stage (e.g. mean or median age plus age range) and } \\
\text { weight (e.g. mean or median weight plus weight range). } \\
\text { b. Provide further relevant information such as the source of animals, } \\
\text { international strain nomenclature, genetic modification status (e.g. } \\
\text { knock-out or transgenic), genotype, health/immune status, drug or test } \\
\text { naïve, previous procedures, etc. }\end{array}$ & $\begin{array}{l}\text { a. Material } \\
\text { and } \\
\text { Methods, } \\
\text { Paragraph } \\
6 \\
\text { b. Material } \\
\text { and } \\
\text { Methods, } \\
\text { Paragraph } \\
6\end{array}$ \\
\hline
\end{tabular}




\begin{tabular}{|c|c|c|c|}
\hline $\begin{array}{l}\text { Housing and } \\
\text { husbandry }\end{array}$ & 9 & $\begin{array}{l}\text { Provide details of: } \\
\text { a. Housing (type of facility e.g. specific pathogen free [SPF]; type of cage or } \\
\text { housing; bedding material; number of cage companions; tank shape and } \\
\text { material etc. for fish). } \\
\text { b. Husbandry conditions (e.g. breeding programme, light/dark cycle, } \\
\text { temperature, quality of water etc for fish, type of food, access to food } \\
\text { and water, environmental enrichment). } \\
\text { c. Welfare-related assessments and interventions that were carried out } \\
\text { prior to, during, or after the experiment. }\end{array}$ & $\begin{array}{l}\text { a. Material } \\
\text { and } \\
\text { Methods, } \\
\text { Paragraph } 6 \\
\text { b. Material } \\
\text { and } \\
\text { Methods, } \\
\text { Paragraph } 6 \\
\text { c. Material } \\
\text { and } \\
\text { Methods, } \\
\text { Paragraph } 6\end{array}$ \\
\hline Sample size & 10 & $\begin{array}{l}\text { a. Specify the total number of animals used in each experiment, and the } \\
\text { number of animals in each experimental group. } \\
\text { b. Explain how the number of animals was arrived at. Provide details of any } \\
\text { sample size calculation used. } \\
\text { c. Indicate the number of independent replications of each experiment, if } \\
\text { relevant. }\end{array}$ & $\begin{array}{l}\text { a. Material } \\
\text { and } \\
\text { Methods, } \\
\text { Paragraph } 8 \\
\text { b. The } \\
\text { number of } \\
\text { available } \\
\text { control and } \\
\text { SPI031- } \\
\text { coated discs } \\
\text { determined } \\
\text { the amount } \\
\text { of mice used } \\
\text { in this study. } \\
\text { c. Material } \\
\text { and } \\
\text { Methods, } \\
\text { Paragraph } 8\end{array}$ \\
\hline $\begin{array}{l}\text { Allocating } \\
\text { animals to } \\
\text { experimental } \\
\text { groups }\end{array}$ & 11 & $\begin{array}{l}\text { a. Give full details of how animals were allocated to experimental groups, } \\
\text { including randomisation or matching if done. } \\
\text { b. Describe the order in which the animals in the different experimental } \\
\text { groups were treated and assessed. }\end{array}$ & 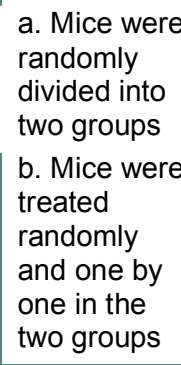 \\
\hline $\begin{array}{l}\text { Experimental } \\
\text { outcomes }\end{array}$ & 12 & $\begin{array}{l}\text { Clearly define the primary and secondary experimental outcomes assessed } \\
\text { (e.g. cell death, molecular markers, behavioural changes). }\end{array}$ & $\begin{array}{l}\text { Material and } \\
\text { Methods, } \\
\text { Paragraph } 6\end{array}$ \\
\hline $\begin{array}{l}\text { Statistical } \\
\text { methods }\end{array}$ & 13 & $\begin{array}{l}\text { a. Provide details of the statistical methods used for each analysis. } \\
\text { b. Specify the unit of analysis for each dataset (e.g. single animal, group of } \\
\text { animals, single neuron). } \\
\text { c. Describe any methods used to assess whether the data met the } \\
\text { assumptions of the statistical approach. }\end{array}$ & $\begin{array}{l}\text { a. Material } \\
\text { and } \\
\text { Methods, } \\
\text { Paragraph } 8 \\
\text { b. For each } \\
\text { test, the } \\
\text { experimenta } \\
\text { unit was an } \\
\text { individual } \\
\text { animal. } \\
\text { c. Material } \\
\text { and } \\
\text { Methods, } \\
\text { Paragraph } 8\end{array}$ \\
\hline \multicolumn{4}{|l|}{ RESULTS } \\
\hline Baseline data & 14 & $\begin{array}{l}\text { For each experimental group, report relevant characteristics and health } \\
\text { status of animals (e.g. weight, microbiological status, and drug or test naïve) } \\
\text { prior to treatment or testing. (This information can often be tabulated). }\end{array}$ & $\begin{array}{l}\text { Material and } \\
\text { Methods, } \\
\text { Paragraph } 6\end{array}$ \\
\hline
\end{tabular}




\begin{tabular}{|c|c|c|c|}
\hline $\begin{array}{l}\text { Numbers } \\
\text { analysed }\end{array}$ & 15 & $\begin{array}{l}\text { a. Report the number of animals in each group included in each analysis. } \\
\text { Report absolute numbers (e.g. } 10 / 20 \text {, not } 50 \%{ }^{2} \text { ). } \\
\text { b. If any animals or data were not included in the analysis, explain why. }\end{array}$ & $\begin{array}{l}\text { a. Material } \\
\text { and } \\
\text { Methods, } \\
\text { Paragraph } 8 \\
\text { b. Data of all } \\
\text { animals was } \\
\text { used }\end{array}$ \\
\hline $\begin{array}{l}\text { Outcomes and } \\
\text { estimation }\end{array}$ & 16 & $\begin{array}{l}\text { Report the results for each analysis carried out, with a measure of precision } \\
\text { (e.g. standard error or confidence interval). }\end{array}$ & $\begin{array}{l}\text { Results, } \\
\text { Paragraph } 2\end{array}$ \\
\hline Adverse events & 17 & $\begin{array}{l}\text { a. Give details of all important adverse events in each experimental group. } \\
\text { b. Describe any modifications to the experimental protocols made to } \\
\text { reduce adverse events. }\end{array}$ & $\begin{array}{l}\text { a. No } \\
\text { adverse } \\
\text { events were } \\
\text { seen } \\
\text { b. No } \\
\text { adverse } \\
\text { events were } \\
\text { seen }\end{array}$ \\
\hline \multicolumn{4}{|l|}{ DISCUSSION } \\
\hline $\begin{array}{l}\text { Interpretation/ } \\
\text { scientific } \\
\text { implications }\end{array}$ & 18 & $\begin{array}{l}\text { a. Interpret the results, taking into account the study objectives and } \\
\text { hypotheses, current theory and other relevant studies in the literature. } \\
\text { b. Comment on the study limitations including any potential sources of bias, } \\
\text { any limitations of the animal model, and the imprecision associated with } \\
\text { the results }{ }^{2} \text {. } \\
\text { c. Describe any implications of your experimental methods or findings for } \\
\text { the replacement, refinement or reduction (the } 3 \text { Rs) of the use of animals } \\
\text { in research. }\end{array}$ & $\begin{array}{l}\text { a. } \\
\text { Discussion, } \\
\text { Paragraph } 4 \\
\text { and } 5 \\
\text { b. No } \\
\text { specific } \\
\text { limitations } \\
\text { were } \\
\text { observed } \\
\text { c. This study } \\
\text { was } \\
\text { performed } \\
\text { simultaneous } \\
\text { ly with } \\
\text { another } \\
\text { study } \\
\text { (Kucharíková } \\
\text { et al., 2015), } \\
\text { thereby } \\
\text { lowering the } \\
\text { number mice } \\
\text { implanted } \\
\text { with control- } \\
\text { Ti discs. }\end{array}$ \\
\hline $\begin{array}{l}\text { Generalisability/ } \\
\text { translation }\end{array}$ & 19 & $\begin{array}{l}\text { Comment on whether, and how, the findings of this study are likely to } \\
\text { translate to other species or systems, including any relevance to human } \\
\text { biology. }\end{array}$ & $\begin{array}{l}\text { Discussion, } \\
\text { Paragraph } 7\end{array}$ \\
\hline Funding & 20 & $\begin{array}{l}\text { List all funding sources (including grant number) and the role of the } \\
\text { funder(s) in the study. }\end{array}$ & $\begin{array}{l}\text { Acknowledg } \\
\text { ments }\end{array}$ \\
\hline
\end{tabular}

References:

1. Kilkenny C, Browne WJ, Cuthill IC, Emerson M, Altman DG (2010) Improving Bioscience Research Reporting: The ARRIVE Guidelines for Reporting Animal Research. PLOS Biol 8(6): e1000412. doi:10.1371/journal.pbio. 1000412

2. Schulz KF, Altman DG, Moher D, the CONSORT Group (2010) CONSORT 2010 Statement: updated guidelines for reporting parallel group randomised trials. BMJ 340:c332. 